\title{
Transmission of the parasitic dinoflagellate Hematodinium sp. infection in blue crabs Callinectes sapidus by cannibalism
}

\author{
Anna N. Walker ${ }^{1, *}$, Richard F. Lee ${ }^{2}$, Marc E. Frischer ${ }^{2}$ \\ ${ }^{1}$ Department of Pathology, Mercer University School of Medicine, Macon, Georgia 31207, USA \\ ${ }^{2}$ Skidaway Institute of Oceanography, 10 Ocean Science Circle, Savannah, Georgia 31411, USA
}

\begin{abstract}
Infection with the parasitic dinoflagellate Hematodinium sp. can be devastating to blue crab Callinectes sapidus populations. Morbidity and mortality appear to depend on the burden of parasitic organisms. Heavily infected crabs become lethargic and, if not preyed upon, succumb to overwhelming infection. We report on the transmission of Hematodinium sp. into blue crabs that were fed pieces of infected tissues and examined for evidence of infection at time periods from 1 to $48 \mathrm{~h}$ and for the general state of their health after $4 \mathrm{~d}$. During the first $16 \mathrm{~h}$ after feeding, Hematodinium sp. was found in the gut, followed by large increases in hemolymph hemocytes and the appearance of hemocytic nodules in tissues. By $16 \mathrm{~h}$, the hemocytic nodules appeared poorly circumscribed and disorganized. No nodules were seen in a heavily infected crab after $24 \mathrm{~h}$. By the end of the $48 \mathrm{~h}$ after feeding, $73 \%$ (11 of 15) of the crabs had shown evidence of infection with Hematodinium sp. Those crabs with infection intensities (Hematodinium sp. as percent of cells in hemolymph) higher than $20 \%$ were dead within $4 \mathrm{~d}$.
\end{abstract}

KEY WORDS: Hematodinium $\cdot$ Callinectes $\cdot$ Blue crab $\cdot$ Dinoflagellate $\cdot$ Disease transmission

\section{INTRODUCTION}

Hematodinium sp. is a parasitic dinoflagellate that has been reported in crabs from many locations, including blue crabs Callinectes sapidus from the east and gulf coasts of the United States. Infection produces a spectrum of disease ranging from asymptomatic carriage to death. The parasite proliferates in crustacean hemolymph and infiltrates other tissues (Field et al. 1992, Love et al. 1993, Field \& Appleton 1995). Morbidity and mortality appear to depend on the burden of parasitic organisms. Heavily infected crabs become lethargic, and loss of hemocytes renders them vulnerable to additional pathogens (Meyers et al. 1987, Stentiford et al. 2003). If not preyed upon, they eventually succumb to overwhelming infection.

We had observed anecdotally that blue crabs feeding on other Hematodinium sp.-infected animals often became infected. Since lethargic animals would be easy prey, we hypothesized that transmission can occur as a result of blue crabs feeding on infected crabs. The following is a brief report on microscopic examinations of hemolymph and tissues from previously uninfected crabs, removed at various times after consumption of infected crab tissues.

\section{MATERIALS AND METHODS}

Fifteen crabs which were to serve as experimental hosts were collected at a station in the Ogeechee River

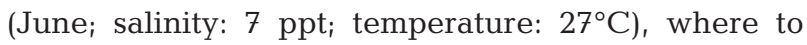
date, Hematodinium sp. has never been detected in crabs (Lee \& Frischer 2004). Small infected crabs are not readily collectable, so we elected to use pooled pieces of heavily infected adult crabs for feeding. 
Crabs ( $n=2$ ) which were to be used as food were collected from pot traps in Wassaw Sound estuary (June; salinity: $30 \mathrm{ppt}$; temperature: $26^{\circ} \mathrm{C}$ ). Both sites are near Savannah, Georgia, USA.

Hemolymph samples were collected from all crabs used in the study at the hemal sinus with a $1 \mathrm{ml}$ syringe, applied to poly-L-lysine-coated microscope slides (Messick 1995), fixed in Bouin's fluid, and stained with Mayer's hematoxylin and eosin (Luna 1968). Infection intensity was the percentage of Hematodinium sp. cells counted among a total of 300 cells from the hemolymph from an individual crab. Identification of and terminology used for the life stages of Hematodinium sp. observed in hemolymph and tissues were based on the descriptions by Stentiford \& Shields (2005).
Microscopic examination of the hemolymph of the Ogeechee crabs revealed that they were parasite-free. The 2 crabs from Wassaw Sound had infection intensities of ameboid trophonts in the hemolymph of 63 and $83 \%$; histological examination verified that their tissues were also heavily infiltrated with ameboid trophonts (Fig.1A). Dinospores were not found; earlier work had indicated that the dinospore form of the parasite, and not the ameboid trophont, was the form that allowed transmission through water (Frischer et al. 2006). Uninfected crabs exposed to water from crabs with the trophont form of Hematodinium sp. did not become infected (R. F. Lee \& M. E. Frischer unpubl. data). The tissues were pooled, and $5 \mathrm{~g}$ were fed to each host crab to keep the dose of the parasite in the food similar throughout the study.
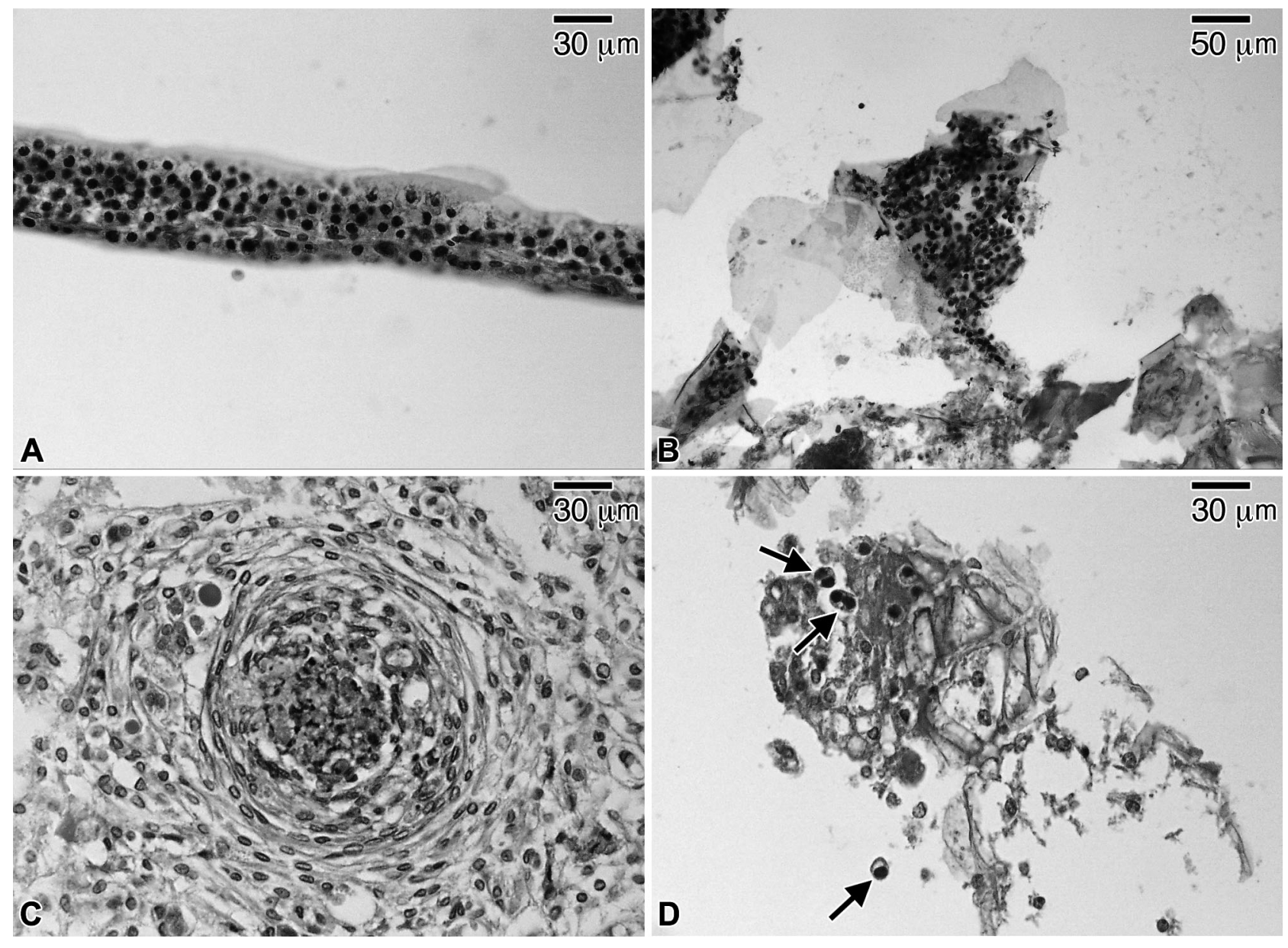

Fig. 1. Callinectes sapidus. (A) Gill from an adult blue crab with a very heavy Hematodinium sp. infection (>80\% of the cells in the hemolymph were parasitic) that was 1 of 2 crabs fed to uninfected blue crabs. Nearly all nucleated cells are parasites; stained with hematoxylin and eosin (H\&E). (B) Tissues from blue crab sacrificed $1 \mathrm{~h}$ after eating infected tissues. Gut contents consist of ingested tissue fragments containing parasites. All nucleated cells visible are parasites; H\&E. (C) Tissues from blue crab sacrificed $3 \mathrm{~h}$ after eating infected tissues. A hemocytic nodule with focal central necrosis is present in the abluminal region of the hepatopancreas; H\&E. (D) Section from hepatopancreatic connective tissue of blue crab sacrificed $6 \mathrm{~h}$ after eating infected tissues; ameboid trophonts are present (arrows); H\&E 
Four experimental host crabs for the transmission studies were sacrificed at $1,3,6$, and $16 \mathrm{~h}$ after feeding. At necropsy, representative portions of gill, cardiac muscle, skeletal muscle, gonad, hepatopancreas, and gut were fixed and processed for routine histological examination. Eleven experimental host crabs that survived $24 \mathrm{~h}, 48 \mathrm{~h}$, and $4 \mathrm{~d}$ after feeding were bled from the hemal sinus, and hemolymph was examined microscopically as described. One of these $24 \mathrm{~h}$ crabs was processed for histological examination.

\section{RESULTS}

1 h after feeding. Hematodinium sp. was not detected in the hemolymph.

Morphologically intact ameboid trophonts were observed intermixed with the gut contents, but there was no invasion of tissues examined (Fig. 1B).

$\mathbf{3} \mathbf{h}$ after feeding. Hematodinium sp. was not detected in the hemolymph. No invasive parasites were seen in the tissues. The number of hemocytes in the hemal spaces appeared increased. Cellular hemocytic nodules were present in the gills and in the hemal spaces between hepatopancreas tubules; the latter had a central region of necrotic-appearing material (Fig. 1C). It was not possible determine if parasites were intermixed.

$6 \mathrm{~h}$ after feeding. Hematodinium $\mathrm{sp}$. was not detected in the hemolymph.

Morphologically intact mononuclear and binucleate ameboid trophonts were found in connective tissue of the hepatopancreas (Fig. 1D). There were numerous hemocytes within hemal spaces and occasional hemocytic nodules in the gills.

$16 \mathbf{h}$ after feeding. Hematodinium sp. was detected in the hemolymph (6\% infection intensity). A few ameboid trophonts were present in fixed sections of the gills. There were also poorly circumscribed aggregates of hemocytes encompassing focally necrotic debris and rare ameboid trophonts in the hepatopancreas and in tissues from the region of the gut.

$\mathbf{2 4} \mathbf{h}$ after feeding. The hemolymph infection intensities of the crabs from this time period are shown in Table 1. Three of 5 crabs bled at $24 \mathrm{~h}$ were infected with intensities of 27,32 , and $37 \%$. In addition, tissues from this last crab were examined. The vascular spaces of the gills were densely populated with ameboid trophonts and vermiform plasmodia. Ameboid trophonts and occasional vermiform plasmodia were also present on abluminal sides of the hepatopancreas and in subjacent vascular spaces. Interstitial infiltrates of ameboid trophonts, hemocytes, and rare vermiform plasmodia were present throughout the cardiac muscle (Fig. 2). Similar infiltrates were focally present in skeletal mus-
Table 1. Callinectes sapidus. Mortality and hemolymph infection intensity (Hematodinium sp. as percent of cells in hemolymph) after blue crabs consumed Hematodinium sp.infected crabs. Crab condition was assessed $4 \mathrm{~d}$ after feeding

\begin{tabular}{|lcccc|}
\hline Crab ID & Gender & $\begin{array}{c}\text { Time after } \\
\text { feeding (h) }\end{array}$ & $\begin{array}{c}\text { Infection } \\
\text { intensity }\end{array}$ & $\begin{array}{c}\text { Crab } \\
\text { condition }\end{array}$ \\
\hline A & Male & 24 & 27 & Dead \\
B & Male & 24 & 32 & Dead \\
C & Male & 24 & 0 & Healthy \\
D & Male & 24 & 0 & Healthy \\
E & Male & 24 & 37 & Dead $^{\text {a }}$ \\
F & Male & 48 & 9 & Healthy \\
G & Female & 48 & 33 & Dead \\
H & Male & 48 & 20 & Lethargic \\
I & Male & 48 & 60 & Dead \\
J & Female & 48 & 0 & Healthy \\
K & Male & 48 & 0 & Healthy \\
a Sacrificed and necropsied after $24 \mathrm{~h}$ & \\
\multicolumn{4}{|l}{} \\
\hline
\end{tabular}

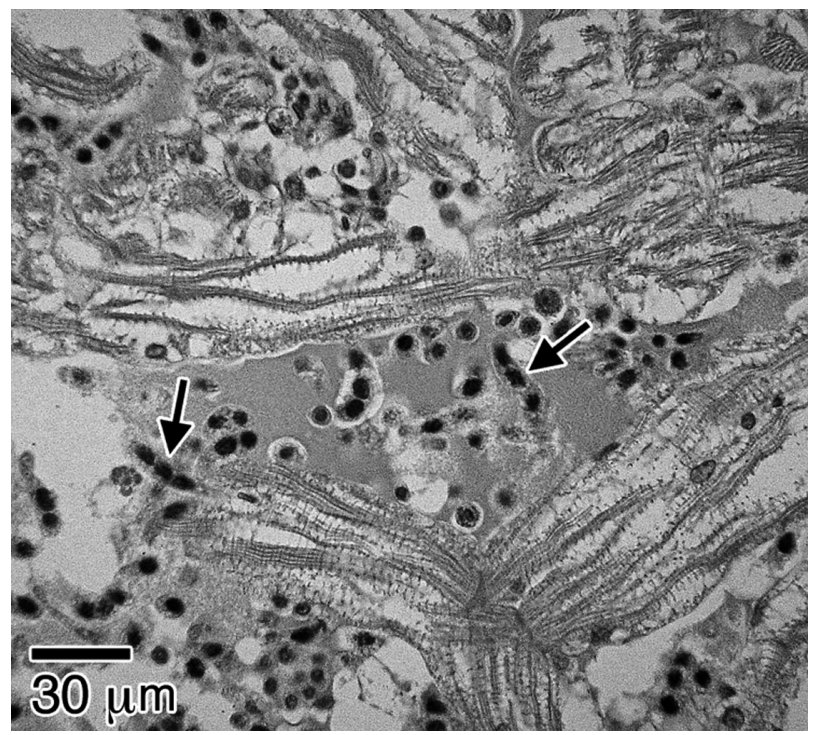

Fig. 2. Callinectes sapidus. Cardiac muscle from blue crab sacrificed $24 \mathrm{~h}$ after eating Hematodinium sp.-infected tissues is heavily populated with ameboid trophonts and vermiform plasmodia (arrows), with parasites outnumbering the remaining hemocytes; stained with hematoxylin and eosin

cle; some muscle fibers were necrotic. Hemocytic nodules were not seen in any of the tissues.

$48 \mathrm{~h}$ after feeding. Four of 6 remaining crabs had become infected with Hematodinium sp. with intensities of 9,20,33, and $60 \%$ (Table 1).

$4 \mathbf{d}$ after feeding. The crabs with infection intensities higher than $20 \%$ had died. Two crabs with 9 and $20 \%$ infection intensities appeared active and lethargic, respectively. Crabs showing no Hematodinium sp. in the hemolymph remained healthy and active. 


\section{DISCUSSION}

Despite the impact of this parasite on commercial fisheries (Lee \& Frischer 2004), the epidemiology of Hematodinium sp. is not completely understood. While a major portal of entry in the Norway lobster appears to be through the midgut (Field et al. 1992, Field \& Appleton 1995), feeding studies in other crab species have not led to similar conclusions. Hudson \& Shields (1994) fed mud crabs Scylla serrata and sand crabs Portunas pelagicus tissues from infected sand crabs, but did not observe transmission of $H$. australis. Infection did occur when these crabs were injected with hemolymph from infected crabs. Similarly, injection of Hematodinium sp. resulted in infection in blue crabs, producing an $87 \%$ mortality rate over a period of $40 \mathrm{~d}$ (Shields \& Squyars 2000).

Possible avenues for the transmission of Hematodinium sp. to blue crabs include water, sediment, fecal material, and food. In a coastal site in Georgia where Hematodinium sp. was found in the water, infectionfree crabs were placed in cages suspended in the water. After $1 \mathrm{~d}$ of exposure, $100 \%(\mathrm{n}=8)$ of the blue crabs were infected with Hematodinium sp. (Frischer et al. 2006). Crabs in cages placed directly on the sediment at this site also became infected. Thus, transmission of Hematodinium sp. into blue crabs may take place after exposure to water and sediments harboring the parasite.

Hematodinium sp. has been demonstrated by microscopic examination in amphipods found in the sediment of endemic waters (Messick \& Shields 2000). Consumption of infected amphipods or other susceptible species by blue crabs could be another avenue of disease transmission. In previous surveys of Georgia estuarine waters, several crustacean species other than blue crabs also exhibited Hematodinium sp. infections (Sheppard et al. 2003). Blue crabs are opportunistic feeders. Sediment and plant material are often found intermixed with other gut contents. As the crabs age and increase in size, they become aggressively cannibalistic, and up to $15 \%$ of the diet of larger crabs is composed of smaller members of their own species (Laughlin 1982, Hines et al. 1990, Hines 2007).

Our observations suggest that the gut can serve as a portal of entry for the parasite. While we witnessed an apparent hemocytosis a few hours after ingestion of the infected tissue, we have consistently observed a markedly decreased hemocyte presence in the hemolymph of dying animals. Depletion of host hemocyte numbers has been observed to parallel an increasing burden of parasites, both in the blue crab and in other crustaceans (Field \& Appleton 1995). Encapsulation by hemocytes is an innate immune response employed by crustaceans to isolate invading organ- isms or foreign bodies that are too large to be phagocytized by individual hemocytes. Hemocytopenia could be due to consumption of cells by the encapsulation process, as more and more hemocytes are needed to control the rising numbers of parasites. Eventually, hemocytes cannot be adequately replenished and the infection proceeds unchecked.

In this study, the hemocytic nodules seen at $16 \mathrm{~h}$ after ingestion of infected tissues were poorly circumscribed and composed in part of necrotic cellular debris. Whether the make-up of these structures was due to the breakdown of previous encapsulations or represented failure of initial nodule formation as the parasite burden increased awaits additional investigation. In one heavily infected crab $24 \mathrm{~h}$ post-feeding, no nodules were seen, suggesting that the host defenses were exhausted after that elapsed time.

Several crabs did not exhibit evidence of Hematodinium sp. after feeding on infected crabs. We hypothesize that in these cases, small numbers of Hematodinium sp. invade tissues, but that the host hemocytic response is sufficient to defend against the parasites by encapsulating them in hemocytic nodules. It is possible to draw an analogy here with human infectious granulomatous diseases. A granuloma confines an infectious organism that cannot be killed by a professional phagocyte, restricting the spread and replication of that organism but not eliminating it. Such structures may then serve as foci of latent infection that can reactivate when the host becomes weakened by stress or otherwise immunologically compromised (McAdam \& Sharpe 2005). While we have not identified hemocytic nodules in healthy crabs, the apparent absence may be due to the fact that the numbers are too small to be detected by our tissue sampling method. If nodules persist in healthy crabs and contain viable Hematodinium sp., active infection may develop when environmental conditions more advantageous to Hematodinium sp. ensue.

Acknowledgements. We gratefully acknowledge the technical assistance of J. Knight and S. Powell, HT (ASCP). This work was partially supported by NOAA National Sea Grant College Marine Environmental Biotechnology Program (NA 06RG0029) to M.E.F and R.F.L. and by an award from the US National Science Foundation (OCE-08-25999) to M.E.F.

\section{LITERATURE CITED}

Field RH, Appleton PL (1995) A Hematodinium-like dinoflagellate infection of the Norway lobster Nephropos norvegicus: observations on pathology and progression of infection. Dis Aquat Org 22:115-128

> Field RH, Chapman CJ, Taylor AC, Neil DM, Vickerman K (1992) Infection of the Norway lobster Nephropos norvegicus by a Hematodinium-like species of dinoflagellate on 
the west coast of Scotland. Dis Aquat Org 13:1-15

Frischer ME, Lee RF, Sheppard MA, Mauer A and others (2006) Evidence for a free-living life stage of the blue crab parasitic dinoflagellate, Hematodinium sp. Harmful Algae 5:548-557

Hines AH (2007) Ecology of juvenile and adult blue crabs. In: Kennedy VS, Cronin LE (eds) The blue crab Callinectes sapidus. Maryland Sea Grant College, College Park, MD, p 565-654

Hines AH, Haddon AM, Wiechert LA (1990) Guild structure and foraging impact of blue crabs and epibenthic fish in a subestuary of Chesapeake Bay. Mar Ecol Prog Ser 67: $105-126$

Hudson D, Shields JD (1994) Hematodinium australis n. sp., a parasitic dinoflagellate of the sand crab Portunus pelagicus and mud crab Sylla serrata from Moreton Bay, Australia. Dis Aquat Org 19:109-119

Laughlin RA (1982) Feeding habits of the blue crab, Callinectes sapidus Rathbun, in the Apalachicola estuary, Florida. Bull Mar Sci 32:807-822

Lee RF, Frischer ME (2004) Where have the blue crabs gone: evidence for a drought induced epidemic of a protozoan disease. Am Sci 92:547-553

Love DC, Rice SD, Moles DA, Eaton WD (1993) Seasonal prevalence and intensity of bitter crab dinoflagellate infection and host mortality in Alaskan Tanner crabs Chionoecetes bairdi from Auke Bay, Alaska, USA. Dis Aquat Org 15:1-7

Luna LG (1968) Manual of histologic staining methods of the Armed Forces Institute of Pathology, 3rd edn. McGrawHill, New York

McAdam AJ, Sharpe AH (2005) Infectious diseases. In: Kumar V, Abbas AK, Fausto N (eds) Robbins and Cotran patho-

Editorial responsibility: Dieter Steinhagen,

Hannover, Germany logic basis of disease, 7th edn. WB Saunders, Philadelphia, PA, p 381-386

Messick GA (1995) Laboratory techniques to detect parasites and diseases of blue crabs, Callinectes sapidus. In: Stolen JS, Fletcher TC, Smith A, Zelikoff JT and others (eds) Techniques in fish immunology. 4. SOS Publications, Fair Haven, NJ, p 187-198

Messick GA, Shields JD (2000) Epizootiology of the parasitic dinoflagellate Hematodinium sp. in the American blue crab Callinectes sapidus. Dis Aquat Org 43:139-152

Meyers TR, Koeneman TM, Botelho C, Short S (1987) Bitter crab disease: a fatal dinoflagellate infection and marketing problem for Alaskan Tanner crabs Chionoecetes bairdi. Dis Aquat Org 3:195-216

Sheppard M, Walker A, Frischer ME, Lee RF (2003) Histopathology and prevalence of the parasitic dinoflagellate, Hematodinium sp., in crabs (Callinectes sapidus, Callinectes similis, Neopanope sayi, Libinia emarginata, Menippe mercenaria) from a Georgia estuary. J Shellfish Res 22:873-880

Shields JD, Squyars CM (2000) Mortality and hematology of blue crabs, Callinectes sapidus, experimentally infected with the parasitic dinoflagellate Hematodinium perezi. Fish Bull (Wash DC) 98:139-152

Stentiford GD, Shields JD (2005) A review of the parasitic dinoflagellates Hematodinium species and Hematodinium-like infections in marine crustaceans. Dis Aquat Org 66:47-70

Stentiford GD, Evans E, Bateman K, Feist SW (2003) Co-infection by a yeast-like organism in Hematodinium-infected European edible crabs Cancer pagurus and velvet swimming crabs Necora puber from the English Channel. Dis Aquat Org 54:195-202

Submitted: October 15, 2008; Accepted: April 7, 2009

Proofs received from author(s): June 16, 2009 